\title{
The Analysis of Resilience of Young Successful Entrepreneur
}

\author{
Paramita Pramesti ${ }^{1 *}$, Wiwik Juwarini Prihastiwi ${ }^{1}$ \\ ${ }^{1}$ Faculty of Psychology, University of Muhammadiyah Surabaya, Surabaya, Indonesia \\ "Corresponding author. Email: ppramest@gmail.com
}

\begin{abstract}
In running a business, entrepreneurs need to maintain consistency and business continuity. Unfortunately, the number of successful young entrepreneurs in Indonesia compared to those who are unsuccessful is still very small. This study aims to find out the process and factors that construct the entrepreneurial resiliency who had experienced a downturn in business but had succeeded in generating and sustaining a stable business after the downturn. This research was conducted using case study approach with in depth interview as data collection tool. The subjects of this research are two entrepreneurs who had experienced a downturn in business but had succeeded in generating and sustaining a stable business after the downturn. Data analysis used transcript analysis by reading the transcript and identifying themes, coding and interpreting data. Researcher connected meaningful correlations within the data and presented them into comprehensive analysis. The results of the study indicate that the factors that construct entrepreneur resilience are social support, self-regulation, selfefficacy and adaptive coping strategy. The strategic implementation of emotional-based coping especially religious coping, and persistently performing concrete problem-based coping help the entrepreneur in strengthening and developing the business. The results of this research could be used as a reference to increase the resilience of entrepreneurs who experience severe challenges in their business, to be able to get back up for success.
\end{abstract}

Keywords: resiliency, young entrepreneur, coping strategy, positive adaptation

\section{INTRODUCTION}

Reaching the level of prosperity is not an easy task. It needs fundamental changes, efforts and hard work that are focused and systematic by the State, government, and families, especially individual people to transform it from the present conditions to become entrepreneurs. In the present conditions it can be said that one of the keys to prosperity is entrepreneurship, and entrepreneurship is a very promising profession for good in quality of life by increasing purchasing power. Purchasing power is created by the high income earned as a result of the occupied profession.

At present, for example Singapore is poor in natural resources, but earns a per capita income higher than Indonesia. This number gives the message and the impression that entrepreneurship is a noble profession whose role in building a prosperous society and country is very clear and large, especially when we examine the progress made by other developed countries in the world both in Europe, America, Australia and Asia. Because these countries, especially the government and the people have chosen entrepreneurship as the main profession which is very important and deliberately developed [6].

In the current era, being an entrepreneur is a strategic choice for young people to achieve prosperity. Besides, being an entrepreneur also aims to offer employment opportunities for other young people. However, many risks are still faced by young entrepreneurs, including unstable income, high competition, and failure / bankruptcy. When those young entrepreneurs experience failure or bankruptcy, some of them usually will discontinue their business. while the others are able to rise up and rebuild their business successfully.

Moreover, entrepreneurship in Indonesia has currently developed quite rapidly compared to previous years. Unfortunately, many start-up businesses established by young entrepreneurs cannot run well in long time. In 2012, there were only $1.56 \%$ of $3.1 \%$ young entrepreneurs in Indonesia, categorized as successful entrepreneur [19]. The high number of young entrepreneurs who got failure in business indicates that there are determinants that have not owned by them.

The determinants can be in the form of psychological capital. A business is very dependent on self-entrepreneurs to be able to run the business incessantly, overcome various challenges and problems, and ultimately maintain the business in order to pursue success and develop the business. The psychological capital is more known as "resilience". Psychological resilience, furthermore, is the capacity of individuals to be able to cope with significant changes, difficulties, or risks.

Gaemezy and Masten; Horward and Johnson, and Luther et al. even argue that resilience is the capacity or ability to adapt in a challenging or pressing environment [16]. Meanwhile, others suggest that resilience is the capability to "cope" and be healthy again to face misery, trauma, or stress. Hence, resilient people are individuals who show the capacity to remain good, recover, or even develop in coping misery [7], [9].

According to Machfoedz [13] everyone who had just started built business are commonly feel optimistic, but it will fade 
when failure occur, usually it happens in the first two years. Only about 20 percent new company can stay existed. There are many reasons presented by start-up entrepreneurs towards their failure such as competitors, high bank interest rates, uncertain economy and various other reasons.

Entrepreneurs frequently have certain characteristics that are different from common people. Meredith in Sarwoko dkk [23] stated the characteristics and character of an entrepreneur include: 1) confidence and optimism, 2) Task and results oriented, have a need for achievement, are financially oriented, have strong motivation, are energetic, persevering, have a determination to work hard, and have high initiative, 3) dare to take risks and like challenges, 4) having a leadership spirit, easy to adapt to others, and open to suggestions and criticisms, 5) high originality, innovative, creative and flexible character, 6) goal oriented, has a vision and perspective on the future. Among those characteristics, resilience as psychological capital is one of the most important features since business is mostly exposed to risks and challenges.

In addition, resilience of businessmen is an important construction in entrepreneurship for several reasons. First, it captures cognitive processes that describe how entrepreneurs deal positively with challenges, setbacks related to their business, and the creation of new ventures. Resilience, in other words, allows individual entrepreneurs to recover from failure or survive in difficult times [10]. Second, it provides insight about the existence of a number of successful companies and failed ones. Third, psychological resilience can be developed, so resilience in entrepreneurship can be taught in entrepreneurship education [2].

According to Masten [14], there are 9 adaptive systems which are very important in resilience, divided into internal and external factor. The internal factors are a) Learning system from human brain (problem solving and information processing), b) Attachment system (close relationship with friends, partner and spiritual figure), c) Mastery Motivation system (self-efficacy and reward system related by successful attitude), d) Stress response system (alarm and recovery system), and e) Self-regulation (emotion regulation).

Flyn et. al. [7] stated that resources that strengthen resilience is ease temperament, flexible personality, optimistic, positive perspective towards self, self-efficacy, sense of meaning, self-regulation towards awakening and impulse, sense of humor. The external factors are: a) Family system (child nurture, interpersonal relationship, expectations, norms, habits and cohesive relationship), b) Peer system (friendship, peer group, value, norm), and c) Cultural and societal system (religion, tradition, ritual, values, law).

According to Reivich and Shatte [17], there are seven factors that become components or main domain of resilience, those are: 1) Emotion Regulation, 2) Calming, 3) Focusing, 4) Impulse Control, 5) Optimism, 6) Causal Analysis, 7) Empathy, 8) Self efficacy, and 9) Reaching out is ability of individual to obtain positive aspect after experiencing severity.

Based on the description above, this research aims to reveal what factors support resilience and how the dynamics of resilience of entrepreneurs who have experienced business bankruptcy, but are still able to bounce back and pursue success.

\section{RESEARCH METHODS}

This research used a case study design since it enables researchers to gain a complete and integrated understanding of the interrelation of various facts and dimensions of the case [22]. The data were collected through interview and observation. The interview technique used was a semistructured interview, an interview based on general guidelines listing the issues that must be discussed without specifying the order of questions. Two successful young entrepreneurs who had previously experienced bankruptcy then were selected as the research subjects.

Subsequently, the data collected were analysed as follows: 1) Transcriptions were made and then the data collected were managed, 2) The data were carefully read repeatedly, 3) Coding and data analysis were conducted by compiling verbatim transcripts or field notes, numbering on the transcript line in sequence, as well as giving a name to each file with a specific code considered as the most appropriate one representing the file, 4) Category patterns in the data were mapped. At this stage, the categories or themes of each subject are put together to produce data patterns that help to identify broader general themes to provide a comprehensive understanding. At this stage, theme synthesis, a coherent summary and combination of all themes on each subject, then was conducted. Next, the researchers explained general themes as well as unique themes emerged on each subject, and 5) The data were interpreted, started from what the respondent said directly to develop a meaningful relationship structure not displayed in the text [20].

\section{RESULTS AND DISCUSSION}

Entrepreneurs are always exposed to various challenges in building their businesses. Both subjects who initially worked as employees then turned to entrepreneurship, initially building the business with hard work and persistence trying to get orders and overcome various difficulties until the business develops and employs enough employees. Both of these efforts have been successful for several years, but then in the middle of the journey, both subjects failed with the same cause, since they put too much trust in partners and lack of control in the work process. This could be due to the fact that both subjects had undergone a business process that was quite successful for more than five years, hence self-efficacy was high enough to undergo the business. This failure could be caused by less critical and lack of awareness of the risks of new business development, specifically understanding and controlling business processes.

Self-efficacy is a belief or confidence in oneself to be able to regulate the function of themselves as humans and their emotional well-being through cognitive processing, motivational, affective and selective processes [21]. In business, self-efficacy plays a very important role in creating a business, but if it is not proper and not followed by control, for example, too much trust in business partners 
social support including cultural influence, community support and personal support.

Both subjects did emotional based coping to deal with stress. The internal process of the subject involves drawing closer to religion, giving positive meaning to unpleasant events, motivating and convincing oneself and looking for reinforcing reasons to be grateful. This is consistent with what was stated by Hendriani [11], namely four coping strategies pursued by individuals in achieving resilience, namely:

a. Give a positive meaning to unpleasant events.

b. Motivate and convince self

c. Look for reinforcing reasons to be more grateful

d. Be realistic

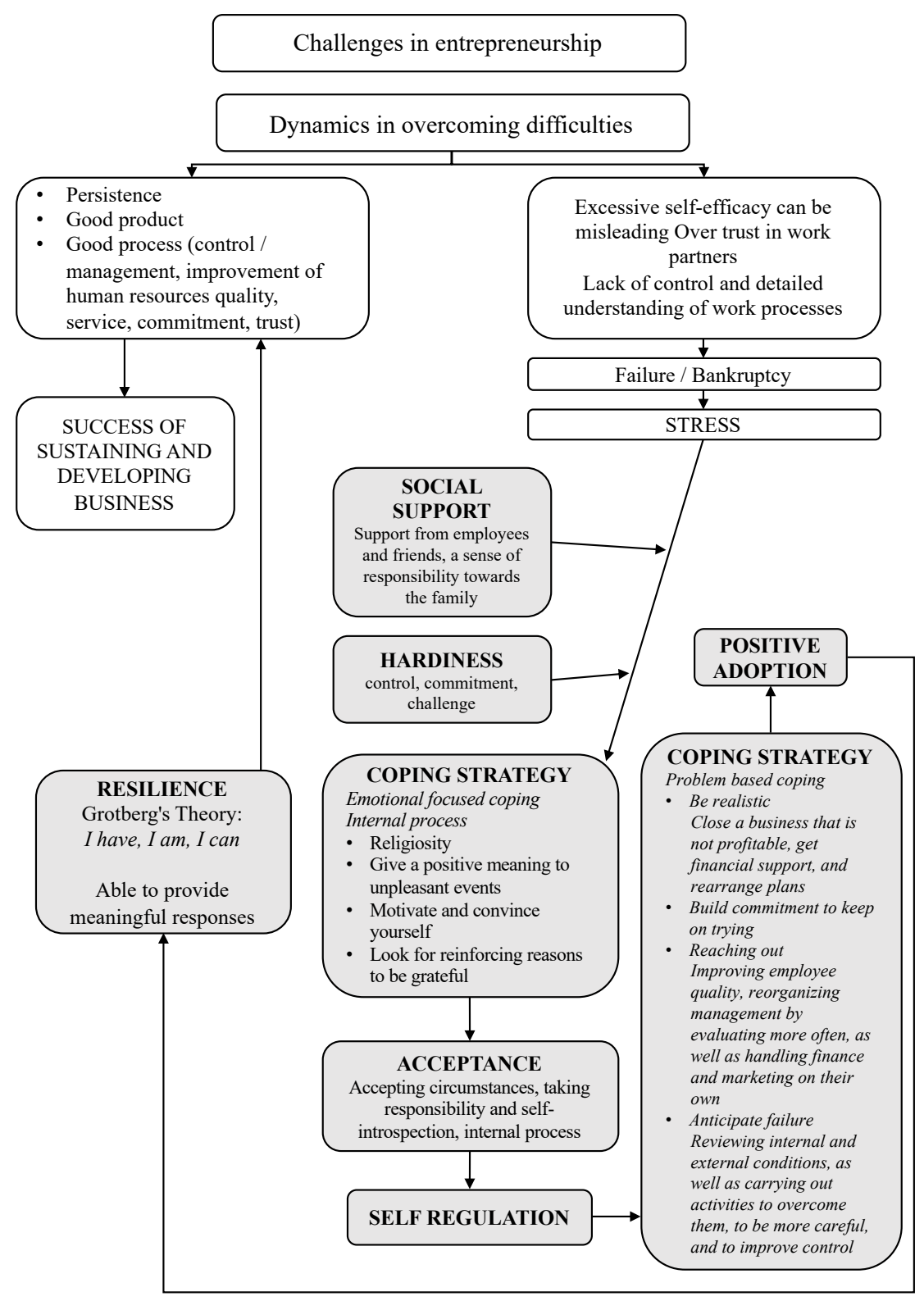

Figure 1. The Dynamics of Subject Resilience Process 
The self-approach to religion is one of the main coping strategies undertaken by both subjects. According to Hardjana in Aisha [1], one of which influences a person's resilience is his level of religiosity. Religiosity is the feeling and awareness of the relationship and rebound with God. Religiosity refers to the level of individual interest in his religion by living and internalizing the teachings of his religion so that it influences in all his actions and outlook on life.

Kasen et al in Scherer et al add that religion can protect the individual against depression, since it seems to minimize the threat that adversity carries. Qualitative research conducted by Scherer et al [18] towards businessmen in Brazil that experience failure, they admit that faith in God help them to survive [18].

Recent studies have shown that positive religious coping consistently shows a strong relationship to positive adjustment after crises. Progress has also been made in operationally defining positive religious coping. Examples of positive religious coping activities significantly linked to positive psychological adjustment in the Western traditions include religious purification, forgiveness, seeking support from clergy and/or faith community members, collaborative religious coping, religious surrender, and benevolent religious reappraisal [5].

According to Foy et al [5], clinicians need to be aware of spiritual "red flags" that may be part of the problem their clients are experiencing in their recovery attempts. Loss of faith and cognitive distortions about lack of forgiveness and guilt per se may present formidable obstacles in the path to trauma recovery, and they may disallow the use of positive religious and other coping practices that might otherwise promote recovery. For clients mired in these "red flags," clinicians might consider referral to a member of the clergy for help in their resolution.

Emotional based coping helps the subject to accept situations, introspect and take responsibility for the situation. If the subject cannot accept the situation then it will be difficult to rearrange. Schultz [3] states that individuals who accept themselves mean to accept their own codes, that is, to accept the strengths and weaknesses they possess without complaining, so that in the event of unpleasant events individuals are able to think logically about the bad the situation without provoking feelings of hostility, humility, shame and insecurity.

After the acceptance process, the two subjects did selfregulation, namely reorganizing themselves and also reorganizing their business systems. Sautelle et al in Fatmawati argue that, self-regulation skills are thoughts, feelings and actions that are intentionally generated by individuals to set and achieve structured goals. Based on some of the notions that have been described, it can be concluded that self-regulation is the ability to control, organize, plan, direct, and monitor behaviour to achieve a certain goal by using certain strategies and involves physical, cognitive, motivational, emotional, and social elements [4].

The process of self-regulation is manifested by both subjects by taking concrete steps based on problem coping. The problem-based coping taken by the subjects is to be realistic by evaluating the management that has been carried out so far, making re-planning and improving management and making efficiency. Both subjects build commitment, try to anticipate failure and reaching out, which is taking positive meaning from the incident and take corrective action to overcome the problem.

According to Hendriani [11] positive adaptation is a simultaneous action of the previous coping that has been taken by the individual. Adaptation points out on the efforts to change various response from previously emerged response to be a new response that is more suitable with the altered condition, by: changing perception, finding new way to do activities, giving reward to themselves.

The process of resilience that occurs until the subject is able to rise again from failure shows that both subjects have three resilience component factors namely, I have (external supports), I am (inner strengths) and I can (interpersonal skills and problem solving) that will affect individual behaviour to be relatively stable, with meaningful responses to various situations and conditions encountered [8]. In the factor I have both subjects get social support from employees and friends, then after failure occurs both subjects are also able to get the trust of clients who are willing to pay up front and keep ordering. In factor I am both subjects appear to have a high concern for others, both family and employees, have a sense of responsibility towards themselves and can accept the consequences for all his actions.

In addition, Grotberg in Scherer et al. [18], points out that considering resilience as a process is not simply a response to adversity, but promotion of factors, behaviours and resilient result; characterizing the dynamics of resilience. In this sense, the author identifies four different categories of resilient factors: I have (support), I am (refers to development of the internal force) and I can (acquisition of interpersonal skills and solving conflicts). As for resilient behaviour, it is necessary to identify the problem and try to select the level and type of response, appropriate to a dynamic interaction with resilient factors. With regard to the promotion of resilient results, the idea does not end in overcoming, but in benefitting from the experienced situation, in other words, learn from the experience and estimate the impact that the adverse situation had on others. According to Grotberg [8], I can be a source of resilience related to the work done by someone in solving problems to success with one's own strength. I can contain an assessment of self-ability that includes the ability to solve problems, social and interpersonal skills. Both subjects depict I can that they have good solving abilities as outlined in problem-based solving.

Within the whole resilience process, both subjects are able to manage their feelings, emotions and impulses to be able to regulate themselves and their business, and to take concrete steps such as building client trust strongly to be able to keep the business survive and develop until now.

\section{CONCLUSION}

Since the number of successful young entrepreneurs in Indonesia compared to those who are unsuccessful is still very small, this study aims to find out the process and factors that construct the entrepreneurial resiliency who had experienced a downturn in business but had succeeded in 
Skripsi. Yogyakarta: Fakultas Psikologi dan Ilmu Sosial Budaya, Universitas Islam Indonesia. (2018).

downturn.

This research was conducted using case study approach with in depth interview as data collection tool. The subjects of this research are two entrepreneurs who had experienced a downturn in business but had succeeded in generating and sustaining a stable business after the downturn. Data analysis used transcript analysis by reading the transcript and identifying themes, coding and interpreting data. Researcher connected meaningful correlations within the data and presented them into comprehensive analysis. The results of the study indicate that the factors that construct entrepreneur resilience are social support, self-regulation, self-efficacy and adaptive coping strategy.

The ability to rise up from pressure due to business failure is a psychological dynamism that goes through several stages. The first stage is self-regulation by coping using a religious approach as an effort to overcome negative emotions. Religion is a source of strength because religion is a demand of human life. The next step is doing problemfocused coping, by evaluating, improving management and efficiency. The success to revive by organizing its business will also be determined by self-efficacy. Besides these factors, social support has a very large role in helping in the resilience process.

The resilience process shows that the two subjects have three components of resilience namely I have, I am, I can so that they can provide meaningful responses to failure and rise again. Concrete steps were taken to overcome the problem.

The strategic implementation of emotional-based coping especially religious coping, and persistently performing concrete problem-based coping help the entrepreneur in strengthening and developing the business. The results of this research could be used as a reference to increase the resilience of entrepreneurs who experience severe challenges in their business, to be able to bounce back and seize for success.

\section{REFERENCES}

[1] Aisha, D. L. "Hubungan antara religiusitas dengan resiliensi pada remaja di panti asuhan keluarga yatim Muhammadiyah Surakarta". Naskah Publikasi Fakultas Psikologi Universitas Muhammadiyah Surakarta,2014

[2] Awotoye, Y. and Robert, P. S. (2017).

Entrepreneurial resilience, high impact challenges, and firm performance. Journal of Management Policy and Practice, Vol 18(2), 2017

[3] Dumaris, S. dan A. R.. Penerimaan diri dan resiliensi hubungannya dengan kebermaknaan hidup remaja yang tinggal di panti asuhan. Jurnal Ikraith Humaniora, Vol. 3(1). 2019

[4] Fatmawati, I. "Hubungan antara regulasi diri dan resiliensi pada remaja di keluarga yang bercerai".
[5] Foy, D.W., Drescher, K.D, and Watson, P. J.. "Religious and spirituality factors in resilience". ReserachGate Article January. 2011.

[6] Frinces, Z. H.. "Kewirausahaan dan Inovasi Bisnis", Cetakan Pertama, Yogyakarta: Penerbit Darusalam, 2004

[7] Flyn, R.J., Ghazal, H., Legault, L., Vandermeulen, G., Petrick, S.. "Use of population measures and norms to identify resilient outcomes in young people in care; an exploratory study". Child and Family Social Work Journal,Vol. 9. , 2004.

[8] Grotberg, E. "Tapping your inner strength : how to find the resilience to deal with anything". Oakland, CA : New Harbinger Publications, Inc. (1999).

[9] Hardy, S.E., Concato, J., Gill, T. M.. "Resilience of Community-Dwelling Older Persons." New York: Mc Graw Hil, 2004

[10] Hayward, M., Foster, W.R., Sarasvathy, S.D., \& Fredrickson, S.. "Beyond hubris: How highly confident entrepreneurs rebound to venture again".Journal of Business Venturing, Vol. 25, 2010.

[11] Hendriani, W. (2018). Resiliensi psikologis. Jakarta: Prenadamedia Group.

[13] Machfoedz, M. "Kewirausahaan Metode, Manajemen, dan Implementasi". Yogyakarta: BPFE, 2015.

[14] Masten,A. Ordinary Magic, "Resilience Processes in Development",. American Psychologist Journal, 56(3), 2001.

[15] Mufidah, A. C. "Hubungan antara dukungan sosial dan resiliensi dengan locus of control sebagai moderator pada mahasiswa bidikmisi". Jurnal Psikodimensia, Vol. 16 (2), 2017.

[16] Parker, H. S." Cultivating educational resilience: an examination of teacher-student interactions in the elementary classroom". University. F New Orleans, Hsparker@uno. 2013.

[17] Reivich, K. dan Shatte, A." The Resilience Factor. 7 Key to Finding Your inner Strenght and Overcoming life's Hurdles". USA; Broadway Books, 2002.

[18] Ricardo S., M. I. F. S.. "Resilience in the face of business failure: A Brazilian study on entrepreneurial behavior". Journal of Business and Management Review, 4 (7), 2015. 
[22] Yin, R. K." Studi kasus desain dan metode". jakarta: Raja Grafious Andndo Perkasa, 2002.

Miskin Pengusaha. Kasetsart, Journal of Social Sciencesompas.

[20] Smith, J. A. "Qualitative psychology: A practical guide to research methods". 2009. Washinton DC:

Sage. 2009.

[21] Utami, C.T dan Helmi, A. F. (n.d.). "Self efficacy dan resiliensi: sebuah tinjauan meta analisis". Buletin Psikologi, 2(1), 2017.
[23] Sarwoko, E., Surachman, Armanu, D.H. Entrepreneurial Characteristics and Competencyas Determinants of Business Performance in SMEs. OSR Journal of Business and Management (IOSR-JBM), 7(3). 2013. 